\title{
Two Distinct Domains in the Yeast Transcription Factor IID and Evidence for a TATA Box-Induced Conformational Change
}

\author{
PAUL M. LIEBERMAN, MARTIN C. SCHMIDT, C. CHENG KAO, AND ARNOLD J. BERK* \\ Department of Microbiology and the Molecular Biology Institute, University of California, \\ Los Angeles, Los Angeles, California 90024-1570
}

Received 12 July 1990/Accepted 1 October 1990

\begin{abstract}
Transcription factor IID from Saccharomyces cerevisiae (YIID) binds the TATA box element present in most RNA polymerase II promoters. In this work, partial proteolysis was used as a biochemical probe of YIID structure. YIID consists of a protease-sensitive amino terminus and a highly stable, protease-resistant carboxy-terminal core. The cleavage sites of the predominant chymotrypsin- and trypsin-derived fragments were mapped to amino acid residues 40 to 41 and 48 to 49 , respectively, by amino-terminal peptide sequencing. Removal of the amino terminus resulted in a dramatic increase in the ability of YIID to form a stable complex with DNA during gel electrophoresis mobility shift assays and a two- to fourfold increase in DNA-binding affinity, as assayed by DNase I footprinting analysis. The carboxy-terminal 190-amino-acid core was competent for transcription in vitro and was similar in activity to native YIID. DNA containing a TATA element induced hypersensitive sites in the amino-terminal domain and stabilized the core domain to further proteolytic attack. Native YIID did not bind to a TATA box at $0^{\circ} \mathrm{C}$, whereas the carboxy-terminal DNA-binding domain did. These results suggest that YIID undergoes a conformational change upon binding to a TATA box. Southern blotting showed that the carboxy-terminal domain is highly conserved, while the amino-terminal domain diverged rapidly in evolution, even between closely related budding yeasts.
\end{abstract}

The regulation of transcriptional initiation by RNA polymerase II involves combinations of interactions between tissue-, temporal-, and sequence-specific factors and a set of proteins referred to as the general transcription factors (reviewed in references 34 and 37). At least five general transcription factors (TFIIA, -IIB, -IID, -IIE, and -IIF) as well as the 10 polypeptide subunits of RNA polymerase II have been identified $(10,15$; reviewed in reference 45$)$. The assembly of the general transcription factors and RNA polymerase II into a stable complex at specific promoter start sites is an ordered, multistep process that may be regulated at several distinct steps $(4,9,14,21,22,57)$. For most regulated genes, promoter-specific transcription factors bind to DNA sequences usually upstream from the transcription initiation site and through an undefined mechanism alter the rate of RNA polymerase initiation $(40,41)$. In principle, promoter-specific activator proteins could stimulate any component that limits the rate of general transcription factor assembly and RNA polymerase II recognition, initiation, or elongation.

The general transcription factor TFIID binds to the TATA box element of most RNA polymerase II promoters (3) and plays an essential role in the formation of a stable preinitiation complex (9). The binding of TFIID to the TATA element of the adenovirus major late promoter is the first step in the ordered assembly of a transcriptionally competent complex on that promoter $(4,9,57)$. Template commitment experiments and sarcosyl treatment have shown that TFIID binding sequesters general factors in a stable intermediate which excludes the assembly of a transcription complex on a second template added at a later time $(9,21,22,43,48)$. Preincubation of TFIID with a DNA template is also sufficient to overcome the general repression of transcription caused by nucleosome structures assembled in vitro (59). In

\footnotetext{
* Corresponding author.
}

vitro transcription reactions with various templates indicate that TFIID is required for all promoters tested, including promoters that lack an obvious TATA sequence $(6,52)$.

Several lines of evidence suggest that TFIID serves as an important target of some promoter-specific activator proteins (reviewed in references 40 and 41 ). For example, the adenovirus immediate-early protein $\mathrm{E} 1 \mathrm{~A}$ is believed to stimulate transcription of the E1B promoter by activation of the TATA-binding factor. Linker-scanning mutagenesis of the E1B promoter (61) and biochemical fractionation of HeLa cell nuclear extracts (32) indicate that the TATA element and TFIID, respectively, are responsive targets of E1A stimulation. More direct evidence that promoter-specific transcription factors interact with TFIID have come from studies with the upstream activator proteins ATF (27), USF (47), and Gal4 (26), which have been shown to alter the binding properties of partially purified $\mathrm{HeLa}$ cell TFIID fractions downstream of the TATA elements of their respective promoters. Evidence for a direct interaction between the acidic activation domain of VP16 and TFIID has been presented (55).

The cloning of TFIID from various species was facilitated greatly by the identification of an activity in Saccharomyces cerevisiae which complemented mammalian TFIID in an in vitro transcription system $(5,8,29)$. The TFIID activity from $S$. cerevisiae (YIID) was cloned and shown to be identical to the SPT15 gene, a suppressor of a Ty insertion mutation (7, $12,19,28$ 49). YIID complements mammalian TFIID for the reconstitution of basal-level transcription, but several reports suggest that YIID does not support upstream factor activation $(23,25,38,42,52)$. YIID behaves as a monomer on sizing columns (5) and binds to both consensus and some nonconsensus TATA sequences found in most promoters (20). More recently, the genes encoding human $(25,31,38)$, Drosophila (23), fission yeast $(13,24)$, and plant (17) TFIID proteins have been isolated. Comparison of these sequences reveals that TFIID consists of a highly conserved carboxy- 
terminal domain of approximately 180 amino acid residues and a nonconserved amino-terminal structure of variable length. Mutagenesis of YIID demonstrated that the conserved domain was both necessary and sufficient for the in vitro reconstitution of basal-level transcription from several simple promoters (30). Examination of TFIID from various species, as well as studies with an amino-terminal deletion mutant in in vitro transcription reactions, indicated that the nonconserved amino-terminal structure is required for species-specific upstream factor activation of basal-level transcription $(23,38,42)$. However, the Schizosaccharomyces pombe gene can substitute for the $S$. cerevisiae TFIID gene in vivo, even though the two proteins have completely different amino termini (13). Although functional homology may exist between the amino-terminal structures of $S$. cerevisiae and Schizosaccharomyces pombe, the actual role, if any, of the nonconserved amino-terminal structure remains unclear.

To help elucidate the molecular structure of TFIID, we have purified bacterially expressed YIID protein to near homogeneity and used partial endoprotease cleavage assays to probe for structural domains in the protein. Limited proteolysis has been particularly useful in defining proteaseresistant structural domains of multifunctional proteins. Partial proteolysis has been used to map the DNA-binding domains of several transcription factors, including the phage lambda repressor (39), the yeast $\alpha 2$ repressor (46), the Xenopus TFIIIA (53), and yeast (35) and human (1) TFIIIC. In addition to mapping of functional domains, partial proteolysis has been successful for determining conformational changes induced by ligand binding $(11,44,51)$ as well as alternative conformations of DNA-binding proteins bound to functionally distinct recognition sites (56).

\section{MATERIALS AND METHODS}

Purification of YIID. YIID was expressed to high levels and purified from Escherichia coli as described previously $(5,49)$. Several steps in the purification procedure were modified slightly. Soluble extracts from heat-induced bacteria were produced by resuspending frozen bacterial pellets in TE (50 mM Tris Chloride [pH 8.0], $10 \mathrm{mM}$ EDTA, $1 \mathrm{mM}$ phenylmethylsulfonyl fluoride [PMSF]) at a concentration of $1 \mathrm{mg}$ of frozen bacteria to $2 \mathrm{ml}$ of TE. After thawing, the mixture was made $1 \mathrm{mg} / \mathrm{ml}$ in lysozyme, incubated for $30 \mathrm{~min}$ on ice, and then made $0.05 \%$ Nonidet P-40. After an additional 30 min on ice, the solution was made $200 \mathrm{mM} \mathrm{KCl}$ by addition of 0.05 volume of $4 \mathrm{M} \mathrm{KCl}$. The lysed bacteria were transferred to $\mathrm{Ti} 45$ ultracentrifuge tubes and cleared by ultracentrifugation at $230,000 \times g$ for $1 \mathrm{~h}$. The supernatant (approximately $30 \mathrm{mg} / \mathrm{ml}$ ) was diluted $1: 1$ in TE and passed over a DEAE-cellulose column (Whatman DE52) at a ratio of $5 \mathrm{mg}$ of protein per $\mathrm{ml}$ of swollen resin. The flowthrough of the DEAE column was then passed directly over a heparin-agarose column that had been preequilibrated in $\mathrm{T}$ buffer $(100 \mathrm{mM} \mathrm{KCl}, 10 \mathrm{mM}$ Tris Chloride [pH 8.0], $20 \%$ glycerol, $1 \mathrm{mM}$ EDTA, $1 \mathrm{mM}$ PMSF). The heparin-agarose column was washed extensively with $T$ buffer and with several column volumes of $\mathrm{T}$ buffer containing $250 \mathrm{mM} \mathrm{KCl}$. YIID protein was eluted with $T$ buffer containing $400 \mathrm{mM}$ $\mathrm{KCl}$. Elution of YIID protein was monitored by Coomassie brilliant blue staining of sodium dodecyl sulfate (SDS)polyacrylamide gels and by transcription reactions with E1B template and HeLa cell nuclear extracts. The peak fractions from the $400 \mathrm{mM} \mathrm{KCl}$ bump of the heparin-agarose column were pooled, dialyzed into $\mathrm{S}$ buffer $(100 \mathrm{mM} \mathrm{KCl}, 10 \%$ glycerol, $20 \mathrm{mM} N$-2-hydroxyethylpiperazine- $N$-2-ethanesulfonic acid [HEPES; pH 7.9], 1 mM EDTA, 1 mM PMSF) and fractionated by Mono $S$ column chromatography. Approximately $150 \mathrm{mg}$ of protein was loaded onto an 8-ml Mono $S$ column, which was developed with a linear gradient of 100 to $600 \mathrm{mM} \mathrm{KCl}$ in $\mathrm{S}$ buffer. YIID protein eluted typically at $250 \mathrm{mM} \mathrm{KCl}$. The peak fractions from the Mono $\mathrm{S}$ column were used for most assays. Protein concentrations were determined by the method of Bradford (2) and by comparative Coomassie brilliant blue staining with bovine serum albumin (BSA) standards in SDS-polyacrylamide gels.

Plasmids and oligonucleotides. Plasmids pAd1B and pAd1BLS $-48 /-39$ (50) were used as templates for in vitro transcription assays. Double-stranded oligonucleotides used in gel mobility shift assays were the E1B TATA 29-mer (50) and a non-TATA-containing 30-bp oligonucleotide referred to here as $\triangle$ and described previously as $\triangle \mathrm{ZRE} 5$ (33). The probe for DNase I footprinting was derived from the EcoRIHindIII fragment of pAd1B.

Generation of proteolytic fragments of YIID. Endoproteases from Staphylococcus aureus V8 (Sigma type VII-B), chymotrypsin (Sigma type II), and trypsin (Sigma type IX) were stored in D buffer ( $20 \%$ glycerol, $20 \mathrm{mM}$ HEPES [pH 7.9], $1 \mathrm{mM}$ EDTA) in small aliquots and kept at $-70^{\circ} \mathrm{C}$ for up to 6 months. The protease inhibitors chymostatin (Sigma) and soybean trypsin inhibitor (Sigma type I-S) were stored in D buffer at $-20^{\circ} \mathrm{C}$. Chymotryptic and tryptic fragments $C_{2}$ and $\mathrm{T}_{2}$ were prepared by incubating $300 \mathrm{ng}$ of the YIID Mono $\mathrm{S}$ peak fraction with $20 \mathrm{ng}$ of protease at $30^{\circ} \mathrm{C}$. After 15,30 , or $60 \mathrm{~min}$, protease inhibitor chymostatin $(20 \mathrm{ng})$ or trypsin inhibitor $(20 \mathrm{ng})$ was added to the respective proteolytic digest. Mock digestions of YIID, chymotrypsin, and trypsin digestions were performed in parallel, and final concentrations were checked by silver-staining analysis. The digested fractions were frozen at $-70^{\circ} \mathrm{C}$. For analytical protease assays, $250 \mathrm{ng}$ of the YIID Mono S peak fraction was mixed (where indicated) with $0.5 \mu \mathrm{g}$ of poly(dAdT) - poly (dA-dT) [poly(dA-dT)] or poly (dG-dC) - poly(dG$\mathrm{dC}$ ) [poly(dG-dC)] (Pharmacia) or $0.2 \mu \mathrm{g}$ of double-stranded oligonucleotide in the presence of $10 \%$ glycerol, $12 \mathrm{mM}$ HEPES (pH 7.9), $0.5 \mathrm{mM}$ EDTA, $6 \mathrm{mM} \mathrm{MgCl}_{2}$, and $1 \mathrm{mM}$ dithiothreitol (DTT) in a final volume of $12 \mu$ l and incubated for $30 \mathrm{~min}$ at $30^{\circ} \mathrm{C}$ to equilibrate. Then $2 \mu$ l of D buffer with or without $20 \mathrm{ng}$ of protease was added to the YIID samples at $30^{\circ} \mathrm{C}$ for the indicated times. Digestions were quenched immediately by the addition of $2 \times$ Laemmli sample buffer (20\% SDS, $1.4 \mathrm{mM}$ 2-mercaptoethanol, $10 \%$ glycerol, $50 \mathrm{mM}$ Tris Chloride [pH 7.0], 0.5\% bromophenol blue) and heating at $95^{\circ} \mathrm{C}$ for $3 \mathrm{~min}$. It was essential to immediately heat samples, since some protease activity was detected in unheated reactions containing Laemmli buffer. Samples were resolved on $15 \%$ polyacrylamide-SDS gels and stained with silver (60). $\mathrm{NH}_{2}$-terminal amino acid sequences of $\mathrm{C}_{2}$ and $\mathrm{T}_{2}$ were determined as described previously (50).

DNA-binding assays. DNA-binding assay mixtures with YIID, $\mathrm{C}_{2}$, or $\mathrm{T}_{2}$ contained $10 \%$ glycerol, $20 \mathrm{mM}$ HEPES ( $\mathrm{pH}$ 7.9), $0.5 \mathrm{mM}$ EDTA, $1 \mathrm{mM}$ DTT, $6 \mathrm{mM} \mathrm{MgCl}_{2}, 50 \mu \mathrm{g}$ of BSA per $\mathrm{ml}$, and $6 \mathrm{mg}$ of poly(dG-dC) per $\mathrm{ml}$ and were incubated at $30^{\circ} \mathrm{C}$ for $30 \mathrm{~min}$. For gel electrophoresis mobility shift assays, the binding reactions were in a final volume of $15 \mu \mathrm{l}$. Gels were made $6 \%$ polyacrylamide and $0.045 \mathrm{M}$ Trisborate- $0.045 \mathrm{M}$ sodium borate-0.001 M EDTA, preelectrophoresed for $30 \mathrm{~min}$, and run at $100 \mathrm{~V}$ (per 14-cm gel) for 2 to $3 \mathrm{~h}$. DNA-binding reaction mixtures for DNase I footprinting assays were the same as described above except 
that the final volumes were $50 \mu \mathrm{l}$. YIID, $\mathrm{T}_{2}$, or $\mathrm{C}_{2}$ was incubated with the radiolabeled DNA for $30 \mathrm{~min}$ at $30^{\circ} \mathrm{C}$ and then treated with DNase I as previously described (50).

In vitro transcription. In vitro transcription reactions were carried out essentially as described previously (50). Primer extension assays with the pAd1B template were performed with the $\mathrm{B} 1750$ oligonucleotide primer as described previously (50). YIID, $C_{2}$, or $\mathrm{T}_{2}$ was added to a $50-\mu$ l reaction mixture containing $1 \mu \mathrm{g}$ of pAd1B template, $60 \mathrm{mM} \mathrm{KCl}, 6$ $\mathrm{mM} \mathrm{MgCl} 2,12 \mathrm{mM}$ HEPES (pH 7.9), $1 \mathrm{mM}$ DTT, $0.5 \mathrm{mM}$ EDTA, the $B$ and $C$ phosphocellulose fractions of HeLa cell nuclear extracts (10), and $0.5 \mathrm{mM}$ each ribonucleoside triphosphate.

Southern analysis of yeast genomic DNAs. All yeast cells were grown in YEPD medium (containing, per liter, $20 \mathrm{~g}$ of peptone, $10 \mathrm{~g}$ of yeast extract, and $20 \mathrm{~g}$ of dextrose) at $30^{\circ} \mathrm{C}$. To purify genomic DNA, $5 \mathrm{ml}$ of a saturated culture was pelleted, treated with lyticase $(0.32-\mathrm{ml}$ solution of $0.87 \mathrm{M}$ sorbitol, $0.087 \mathrm{M}$ sodium citrate, $0.044 \mathrm{M}$ EDTA, $0.075 \mathrm{M}$ DTT, and lyticase) at $30^{\circ} \mathrm{C}$ for $30 \mathrm{~min}$ to form spheroplasts. The spheroplasts were pelleted and resuspended in $0.5 \mathrm{ml}$ of $1 \mathrm{M}$ sorbitol and then mixed with $0.3 \mathrm{ml}$ of lysis buffer $(4.48$ $\mathrm{M}$ guanidine hydrochloride, $0.144 \mathrm{M} \mathrm{NaCl}, 0.1 \mathrm{M}$ EDTA, 20 $\mu l$ of $1 \%$ sarkosyl) for $10 \mathrm{~min}$ at $65^{\circ} \mathrm{C}$. The DNA was then precipitated with ethanol, resuspended, and digested for $1 \mathrm{~h}$ at $65^{\circ} \mathrm{C}$ with protease $(20 \mu \mathrm{l}$ of $10 \%$ SDS, $10 \mu$ l of a $20-\mathrm{mg} / \mathrm{ml}$ solution of proteinase $\mathrm{K}$ ). DNA was then extracted several times with phenol-chloroform (1:1) and ethanol precipitated. A 10- $\mu$ g sample of DNA was digested with EcoRI or EcoRI and HindIII and electrophoresed in a $0.8 \%$ agarose gel. DNA was checked for equal concentrations by ethidium staining and then transferred to a nylon membrane (Schleicher \& Schuell) as described previously (54). The blotted DNA was probed sequentially with four restriction fragments spanning the YIID gene. Probes were nick translated to a specific activity greater than $5 \times 10^{7} \mathrm{cpm} / \mu \mathrm{g}$ of DNA. The conditions for hybridization were as described previously (49). After hybridization, the membrane was washed $(6 \times$ SSC [SSC is $0.15 \mathrm{M} \mathrm{NaCl}$ plus $0.015 \mathrm{M}$ sodium citrate- $-0.1 \% \mathrm{SDS}$ ) at up to $55^{\circ} \mathrm{C}$ and autoradiographed. The blot was stripped by heating the nylon membrane in $95^{\circ} \mathrm{C}$ water twice for $15 \mathrm{~min}$ each time.

\section{RESULTS}

Identification of a stable proteolytic domain of YIID. YIID was purified to apparent homogeneity from engineered $E$. coli and subjected to limited proteolysis. Conditions for the production of homogeneous proteolytic fragments of YIID were determined for the endoproteases chymotrypsin and trypsin (Fig. 1). Incubation of $300 \mathrm{ng}$ of YIID with $20 \mathrm{ng}$ of chymotrypsin or trypsin yielded stable proteolytic fragments of 22 and $21 \mathrm{kDa}$, respectively, after $1 \mathrm{~h}$ of incubation at $30^{\circ} \mathrm{C}$ (Fig. 1, lanes 7 and 8). Under these conditions we found only one intermediate cleavage product for both chymotrypsin and trypsin, designated $C_{1}$ and $T_{1}$ (lanes 3 and 4). The more stable polypeptides, designated $T_{2}$ and $C_{2}$, were resistant to further protease digestion for up to several hours. The stable $\mathrm{C}_{2}$ and $\mathrm{T}_{2}$ polypeptide fragments were subjected to aminoterminal sequence analysis to map precisely the protease cleavage sites. The $22-\mathrm{kDa}$ chymotrypsin fragment $\left(\mathrm{C}_{2}\right)$ had the amino terminus QSEED (single-letter amino acid code), which results from a cleavage between amino acids $\mathbf{4 0}$ and 41. The 21-kDa tryptic fragment $\left(\mathrm{T}_{2}\right)$ had the amino terminus ATPES, which results from a cleavage between amino acid residues 48 and 49 . Comparison of peptide sequencing and

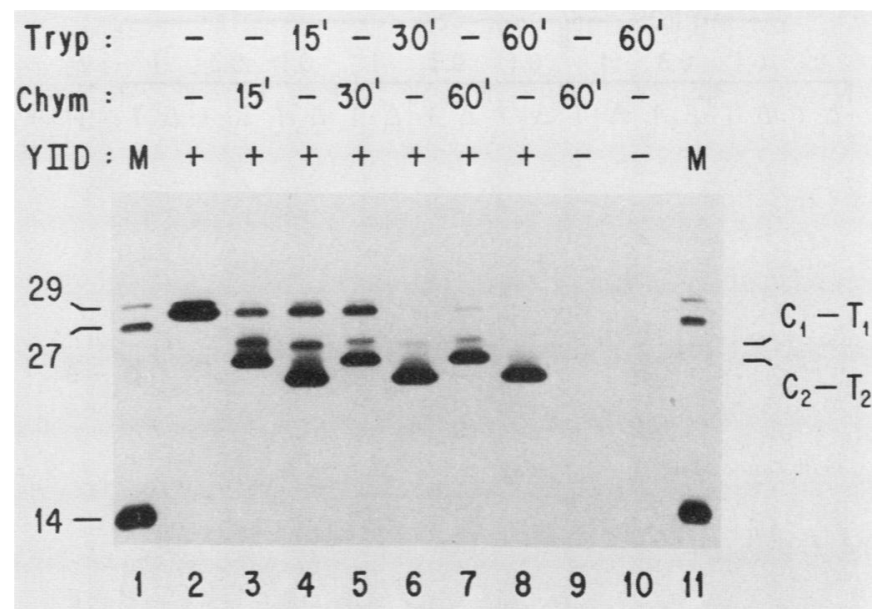

FIG. 1. Silver-stained polyacrylamide gel of the YIID proteolytically stable core. YIID ( $300 \mathrm{ng})$ was incubated with $20 \mathrm{ng}$ of chymotrypsin (Chym; lanes 3, 5, and 7) or trypsin (Tryp; lanes 4, 6, and 8) for 15 (lanes 3 and 4), 30 (lanes 5 and 6), or 60 (lanes 7 and 8) min. Lanes 9 and 10 show chymotrypsin and trypsin, respectively, with no YIID added. Lanes 1 and 11 contain protein molecular weight markers; sizes are indicated on the left in kilodaltons. Full-length YIID is shown in lane 2. The major cleavage products $C_{1}$ and $C_{2}$ for chymotrypsin and $T_{1}$ and $T_{2}$ for trypsin are indicated on the right.

SDS-polyacrylamide gel electrophoresis analysis of molecular mass suggests that little proteolysis occurred at the carboxy terminus of the YIID protein. However, we could not rule out the possibility that one or a few carboxyterminal amino acid residues were removed.

Proteolyzed YIID demonstrates higher affinity for TATA sequences. We found that the full-length YIID protein does not form complexes with DNA that are stable to electrophoresis in polyacrylamide gels under standard low-ionicstrength conditions of the gel mobility shift assay. Buratowski et al. (4) made similar observations. Curiously, we found that after protease treatment, the ability of YIID to remain stably bound to DNA in the gel shift assay was increased dramatically. A comparison of the full-length YIID protein, the chymotryptic $C_{2}$ fragment, and the tryptic $T_{2}$ fragment in the gel electrophoresis mobility shift assay is shown in Fig. 2. We found that the full-length YIID produced only a trace of bound complex when $1 \mathrm{ng}$ of protein was incubated with a 29-bp oligonucleotide probe containing the E1B TATA element (Fig. 2, lane 8). In contrast, TATAspecific binding could be detected with as little as $0.1 \mathrm{ng}$ of the $C_{2}$ (lane 10) or $T_{2}$ (lane 16) polypeptide fragment, derived from the material produced by the digest shown in Fig. 1, lanes 7 and 8. Full-length YIID, as well as the proteolytic fragments $C_{2}$ and $T_{2}$, showed no detectable binding to the control oligonucleotide $\Delta$, which lacks a TATA element, at protein concentrations of up to $1 \mathrm{ng}$ (Fig. 2, lanes 7, 13, and 19).

Despite the inability of YIID to form stable gel shift complexes, the protein readily bound to consensus and some nonconsensus TATA elements in DNase I footprinting assays. When we compared the ability of full-length YIID and the $C_{2}$ and $T_{2}$ proteolytic fragments to footprint over the adenovirus E1B TATA box element, we found a two- to fourfold increase in the affinity of the proteolyzed YIID for the TATA sequence (Fig. 3). The E1B promoter probe was 


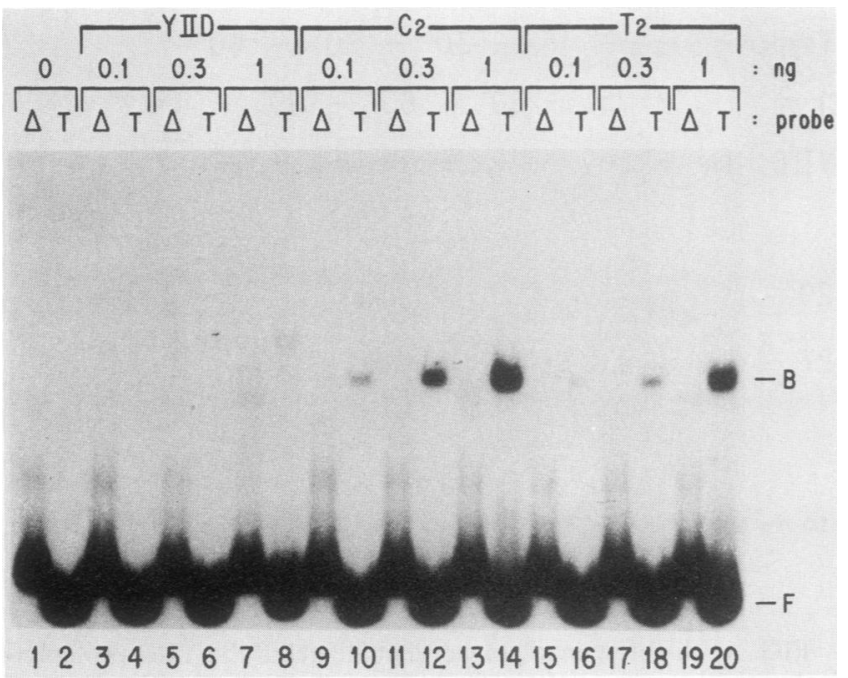

FIG. 2. Gel electrophoresis mobility shift analysis of wild-type and protease-treated YIID. YIID (lanes 3 to 8), $C_{2}$ (lanes 9 to 14), and $T_{2}$ (lanes 15 to 20 ) were incubated with either the control oligonucleotide $\Delta$ (odd lanes) or the E1B TATA-containing oligonucleotide $\mathrm{T}$ (even lanes) for $30 \mathrm{~min}$ at $30^{\circ} \mathrm{C}$. The $\mathrm{C}_{2}$ and $\mathrm{T}_{2}$ products were the same material shown in the 1-h digest in Fig. 1 (lanes 7 and 8). Free (F) and bound (B) probe are indicated on the right.

incubated with $2.5,5,10$, or $20 \mathrm{ng}$ of the full-length YIID or with $C_{2}$ or $T_{2}$ fragment prepared from the material shown in Fig. 1 (1-h digest) and assayed for binding by DNase I protection. Under these conditions, $20 \mathrm{ng}$ of the full-length YIID was required for near-complete protection of the E1B TATA box (Fig. 3, lane 5). In contrast, complete protection of the E1B TATA element was observed with 5 to $10 \mathrm{ng}$ of the $C_{2}$ and $T_{2}$ fragments (lanes 7, 8,13, and 14). Despite the difference in affinity for binding, we did not detect any significant qualitative difference in the footprinting patterns. The extended footprints over the E1B TATA box with 10 and $20 \mathrm{ng}$ of the $\mathrm{C}_{2}$ and $\mathrm{T}_{2}$ polypeptides are characteristic of the full-length protein as well but require higher concentrations than were used in this experiment. Although consistent with the gel mobility shift data, the increase in affinity measured by footprinting was significantly less than the increase found by gel shift analysis.

Transcriptional activity of proteolyzed YIID. The fulllength YIID and proteolyzed $\mathrm{C}_{2}$ and $\mathrm{T}_{2}$ were compared for the ability to stimulate transcription form the E1B template in a HeLa cell extract depleted of human TFIID (Fig. 4). In the absence of any exogenous TFIID, very little transcription was detected from the E1B template (Fig. 4, lane 1). We found that 2.5 to $10 \mathrm{ng}$ of YIID yielded increasing transcription from the E1B promoter (lanes 8 to 10). Remarkably, the proteolyzed amino-terminal deletion products, $C_{2}$ and $T_{2}$, derived from the 1-h-digested material shown in Fig. 1 gave the same levels of transcriptional stimulation as did fulllength YIID (lanes 2 to 7).

TATA box-induced changes in YIID proteolysis pattern. We performed a series of experiments to test whether the binding of YIID to a TATA element might induce conformational changes that can be detected by partial proteolysis. We used the gel mobility shift assay to determine whether any difference could be detected between proteolytic cleavage of YIID in the presence or absence of an oligonucleotide containing the E1B TATA element (Fig. 5). In this assay, 1

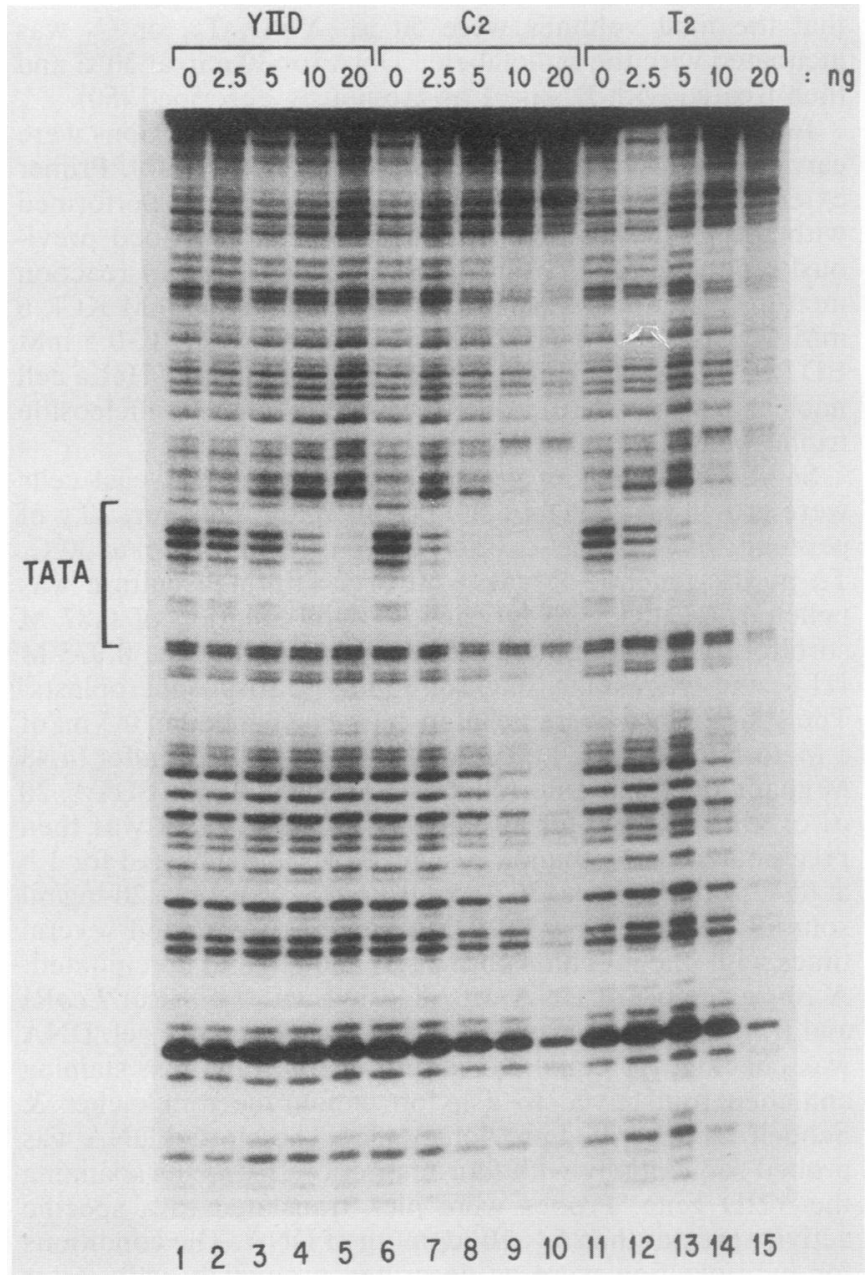

FIG. 3. DNase I footprint of wild-type and protease-treated YIID over the E1B TATA box. YIID (lanes 1 to 5), chymotryptic fragment $C_{2}$ (lanes 6 to 10), and tryptic fragment $T_{2}$ (lanes 11 to 15 ) were incubated with the $\mathrm{E} 1 \mathrm{~B}$ promoter probe for $45 \mathrm{~min}$ at $30^{\circ} \mathrm{C}$. The amount of protein added ranged from 0 to $20 \mathrm{ng}$, as indicated above each lane. The $C_{2}$ and $T_{2}$ proteins were the same as the material shown for the 1-h digest in Fig. 1 (lanes 7 and 8). The protected TATA sequence is shown by the bracket at the left.

ng of YIID was incubated with $50 \mathrm{ng}$ of chymotrypsin either before (Fig. 5, lanes 3, 5, 7, 9, 11, and 13) or 5 min after (lanes $4,6,8,10,12$, and 14) incubation with a TATA oligonucleotide probe. Chymotrypsin digestion was carried out for 1 (lanes 3 and 4) to 75 (lanes 13 and 14) min and then was stopped by addition of $50 \mathrm{ng}$ of chymostatin. The predigested YIID set (lanes 6) then was incubated for an additional $30 \mathrm{~min}$ after the addition of the TATA probe, and then both the $a$ and $b$ samples were subjected to gel electrophoresis. We found that after $60 \mathrm{~min}$ of digestion under these conditions, YIID-binding activity was completely lost from the predigested samples (lanes 11 and 13) but not from the prebound samples (lanes 12 and 14). The formation of a bound complex was dependent on protease treatment, since no binding could be detected with the undigested YIID (lane 2). While bound species were formed almost immediately after protease digestion (1-min time point; lanes 3 and 4), only one major species was observed at later digestion times (lower arrow in Fig. 5), suggesting that 


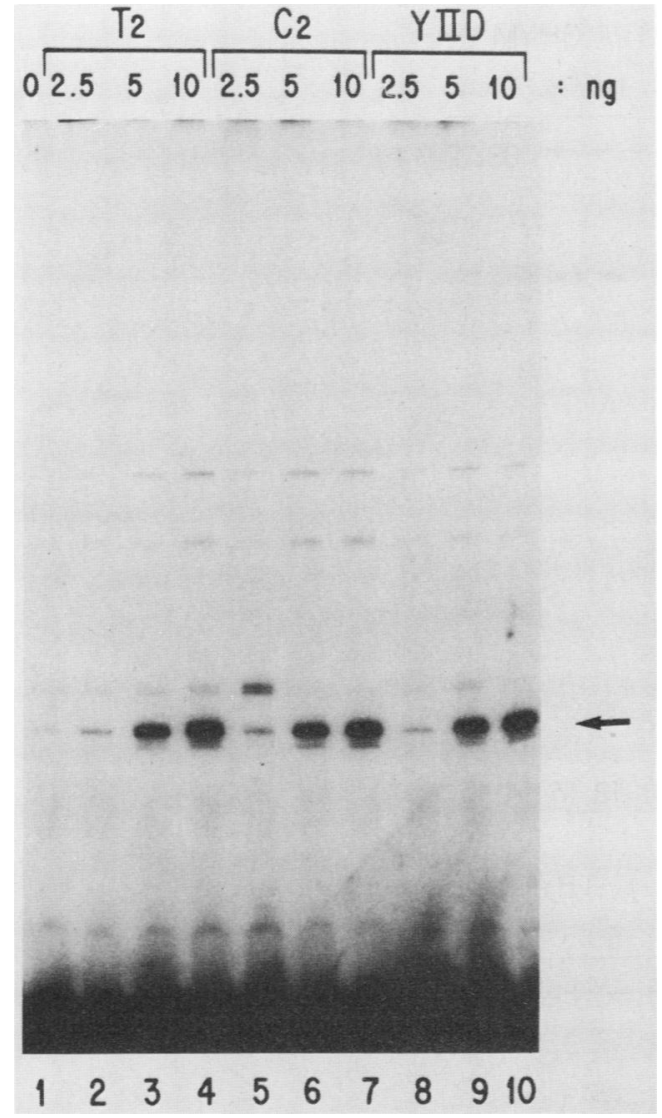

FIG. 4. In vitro transcriptional activity from the E1B promoter with the wild-type and protease-treated forms of YIID. YIID (lanes 8 to 10), chymotryptic fragment $C_{2}$ (lanes 5 to 7 ), and tryptic fragment $T_{2}$ (lanes 2 to 4 ) were added to an in vitro transcription reaction with TFIID-depleted HeLa cell nuclear extract and $1 \mu \mathrm{g}$ of pAd1B template. Background transcription in the absence of exogenous TFIID is shown in lane 1 . The amounts of YIID, $C_{2}$, and $T_{2}$ ranged from 2.5 to $10 \mathrm{ng}$, as indicated above the lanes. Transcribed RNA was measured by primer extension analysis. The correctly initiated transcript is indicated by the arrow at the right.

a predominant DNA-binding core is produced and stabilized by binding to DNA containing a TATA box.

The structural properties of YIID were examined further by observing limited proteolytic patterns of highly purified YIID protein on silver-stained SDS-polyacrylamide gels. We compared the effects of three potential YIID ligands, $\mathbf{M g}^{2+}$ ion, single-stranded DNA, and poly(dA-dT) double-stranded DNA, on the pattern of partial proteolysis. The endoproteases trypsin, chymotrypsin, and $S$. aureus V8 protease were used to increase our chances of mapping both structural domains and changes in protein conformation. In general, we found that poly(dA-dT) and single-stranded DNA, both of which bind to YIID with high affinity, induced two major changes in the protease patterns relative to no DNA and $\mathrm{MgCl}_{2}$ alone. Consistent with our observation from the gel mobility shift assay, we found that doublestranded poly(dA-dT) DNA stabilized a major cleavage product of the YIID protein throughout more extensive periods of proteolysis. Single-stranded DNA induced a similar resistance to proteolytic attack. This was true for each of the three proteases used (Fig. 6Ab). At $8 \mathrm{~h}$ of digestion with

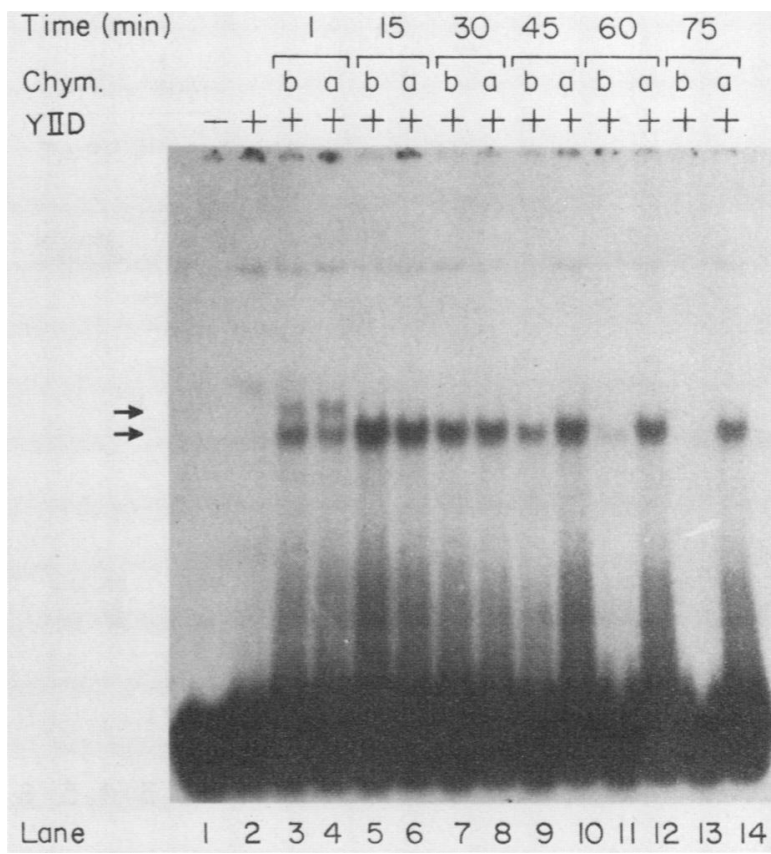

FIG. 5. Demonstration that DNA binding stabilizes the YIID core to further protease digestion. Chymotrypsin cleavage of YIID before or after DNA binding was assayed by gel mobility shift. YIID (1 ng) was mixed with poly (dG-dC) $(5 \mu \mathrm{g} / \mathrm{ml})$ and binding reaction components (see Materials and Methods) in a 10- $\mu$ l volume and then in half of the samples (a) incubated with the radiolabeled E1B TATA oligonucleotide probe for $5 \mathrm{~min}$ at $30^{\circ} \mathrm{C}$ (lanes $2,4,6,8,10,12$, and 14). Chymotrypsin (Chym.; $50 \mathrm{ng}$ ) was added to samples in lanes 3 to 14 , and the samples were incubated for 1 to $75 \mathrm{~min}$, as indicated above the lanes. Chymotrypsin digestions were stopped by the addition of $50 \mathrm{ng}$ of chymostatin. After $75 \mathrm{~min}$, the E1B TATA oligonucleotide probe was added to the other half of the samples (b; lanes $3,5,7,9,11$, and 13), and the samples were incubated for an additional $25 \mathrm{~min}$ at $30^{\circ} \mathrm{C}$. Samples were then loaded on $5 \%$ polyacrylamide gels. Arrows at the left indicate the bound complex.

$S$. aureus $\mathrm{V} 8$, products $\mathrm{V}_{2}$ and $\mathrm{V}_{3}$ were stabilized in comparison with digestion of YIID in the absence of DNA (Fig. $6 A b$, lanes 2 to 5). Trypsin products $T_{2}$ and $T_{3}$ (lanes 7 to 10 ) and chymotrypsin products $C_{2}$ and $C_{3}$ (lanes 12 to 15 ) were similarly stabilized by poly(dA-dT) and single-stranded DNA. Stabilization of $T_{2}$ to trypsin digestion was also observed at 120 and 1,440 min of digestion (Fig. 6B, lanes 13 to 17), as were $S$. aureus $V 8$ digestion products $V_{1}$ and $V_{2}$ at 60 min of digestion (lanes 8 and 9). In almost every case, the proteolytically stable fragment was approximately 21 to 22 $\mathrm{kDa}\left(\mathrm{V}_{3}, \mathrm{~T}_{2}, \mathrm{~T}_{3}, \mathrm{C}_{2}\right.$, and $\left.\mathrm{C}_{3}\right)$.

We also observed that poly(dA-dT) and single-stranded DNA induced hypersensitive sites in YIID at early time points in digestion. The hypersensitive cleavage was most apparent with $S$. aureus V8 protease. At 45 min of digestion, a considerable fraction of full-length YIID remained when digestion occurred in the absence of DNA (Fig. 6A, lanes 2 and 3). Much less intact YIID remained after digestion in the presence of single-stranded DNA or poly(dA-dT) (lanes 4 and 5). Instead, preferential cutting occurred to produce the $\mathrm{V}_{1}$ digestion product. At early time points of proteolysis with $S$. aureus V8 (Fig. 6B), preferential digestion at the $V_{1}$ site was observed at 1,5 , and 10 min of digestion for samples digested in the presence of poly $(\mathrm{dA}-\mathrm{dT})$. The increased rate of digestion in the YIID amino terminus was also observed 

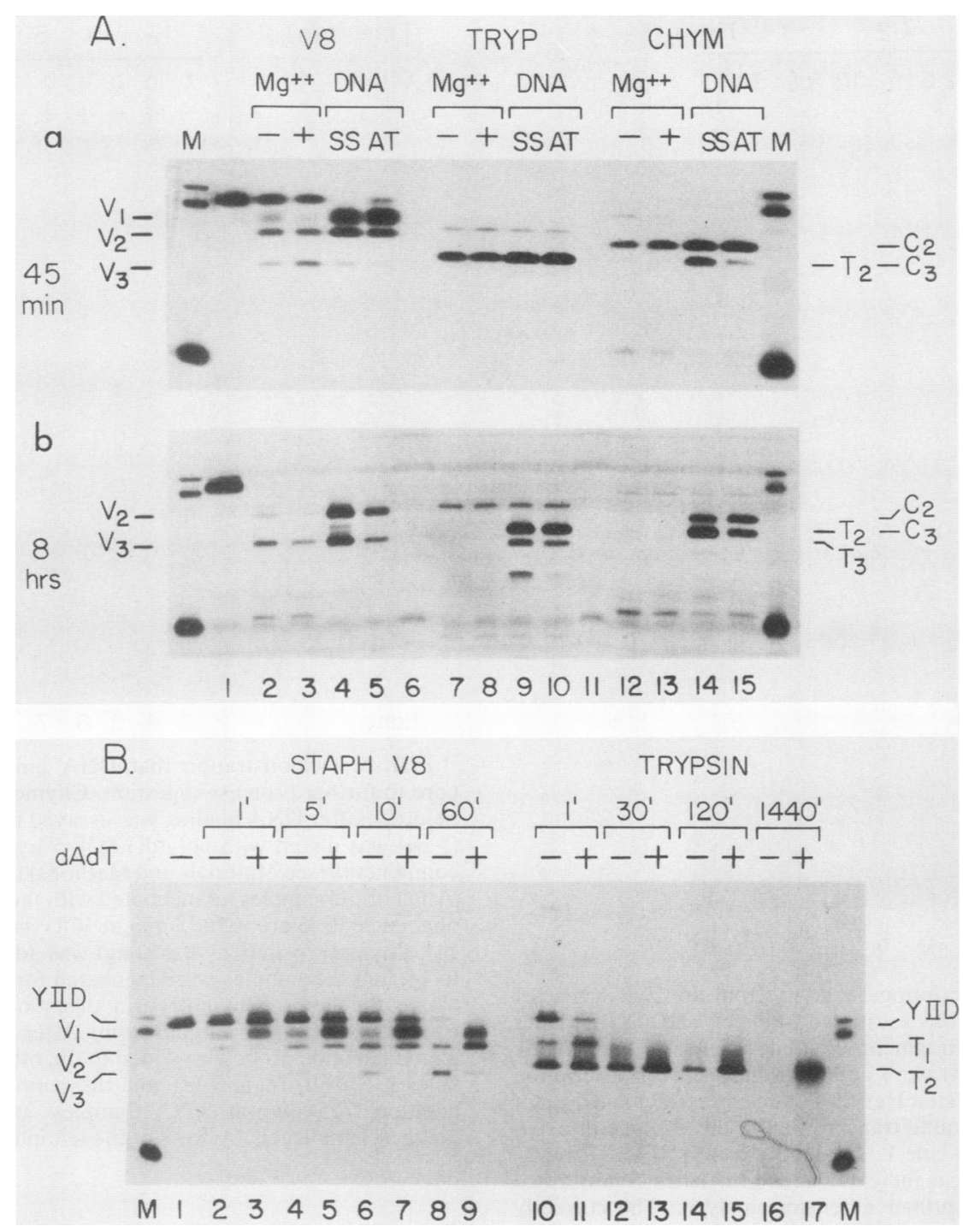

FIG. 6. Protease patterns induced by three ligands of YIID. (A) YIID (250 ng) was incubated with $6 \mathrm{mM} \mathrm{MgCl}_{2}(+;$ lanes 3 , 8, and 13$)$, $500 \mathrm{ng}$ of M13 single-stranded DNA (SS; lanes 4, 9, and 14), $500 \mathrm{ng}$ of poly(dA-dT) (AT; lanes 5, 10, and 15), or buffer lacking $\mathrm{MgCl}_{2}(-;$ lanes 2,7 , and 12). Then $20 \mathrm{ng}$ of $S$. aureus V8 protease (V8; lanes 2 to 6), trypsin (TRYP; lanes 7 to 11), or chymotrypsin (CHYM; lanes 12 to 15) was added to YIID samples, which were incubated at $30^{\circ} \mathrm{C}$ for $45 \mathrm{~min}(\mathrm{a})$ or $8 \mathrm{~h}$ (b). Samples were loaded onto $15 \%$ SDS-polyacrylamide gels and stained with silver. Lane 1 contains undigested YIID; lanes M contain marker proteins of (from top down) 29, 27, and 14 kDa. (B) YIID (250 ng) was incubated with $500 \mathrm{ng}$ of poly(dA-dT) (dAdT) (lanes 3, 5, 7, 9, 11, 13, 15, and 17) or buffer alone (lanes 2, 4, 6, 8, 10, 12, 14, and 16). After $30 \mathrm{~min}$ of incubation at $30^{\circ} \mathrm{C}$, reaction mixtures were treated with $25 \mathrm{ng}$ of $S$. aureus V8 protease (STAPH V8; lanes 2 to 9) or with $25 \mathrm{ng}$ of trypsin (lanes 10 to 17). Digestions were incubated at $30^{\circ} \mathrm{C}$ for the times (in minutes) indicated above the lanes. Undigested YIID was loaded onto lane 1; markers appear in lanes $M$. Major cleavage products of $S$. aureus $V 8$ are indicated as $V_{1}, V_{2}$, and $V_{3}$. Major cleavage products of trypsin are indicated as $T_{1}$ and $T_{2}$.

with trypsin at the 1-min time point (Fig. 6B, lanes 10 and 11). Similar hypersensitivity to digestion in the amino terminus in the presence of poly(dA-dT) was also observed for chymotrypsin after digestion for 15 min with 5,10 , and $20 \mathrm{ng}$ of protease (Fig. 7A). This phenomenon was also observed in the experiment shown in Fig. 7B (lanes 1 to 3 ) and after digestion in the presence of a double-stranded oligonucleotide containing the E1B TATA box compared with digestion in the absence of DNA (Fig. 7C, lanes 1 and 2). This hypersensitivity of the YIID amino terminus to digestion by each protease tested when the protein was bound to DNA was thus reproducibly observed in the several experiments shown and several more not shown.
To determine whether the hypersensitive cleavages at early time points of digestion and the stable species at longer durations of proteolysis were a result of specific interactions with TATA-binding sites or nonspecific effects of DNA in general, we compared the effects of poly(dA-dT) (Fig. 7A, lanes 3, 7, 11, and 15; Fig. 7B, lanes 2 and 6) with the effects of poly(dG-dC) (Fig. 7A, lanes 4, 8, 12, and 16; Fig. 7B, lanes 3 and 7) on YIID digestion by chymotrypsin over time. We consistently found that at early time points, an accelerated cleavage of YIID was induced specifically by the poly(dAdT) copolymer but not by the poly(dG-dC)copolymer. Similarly, poly(dA-dT) stabilized the YIID core polypeptide. This stabilization was not observed with poly(dG-dC) (Fig. 


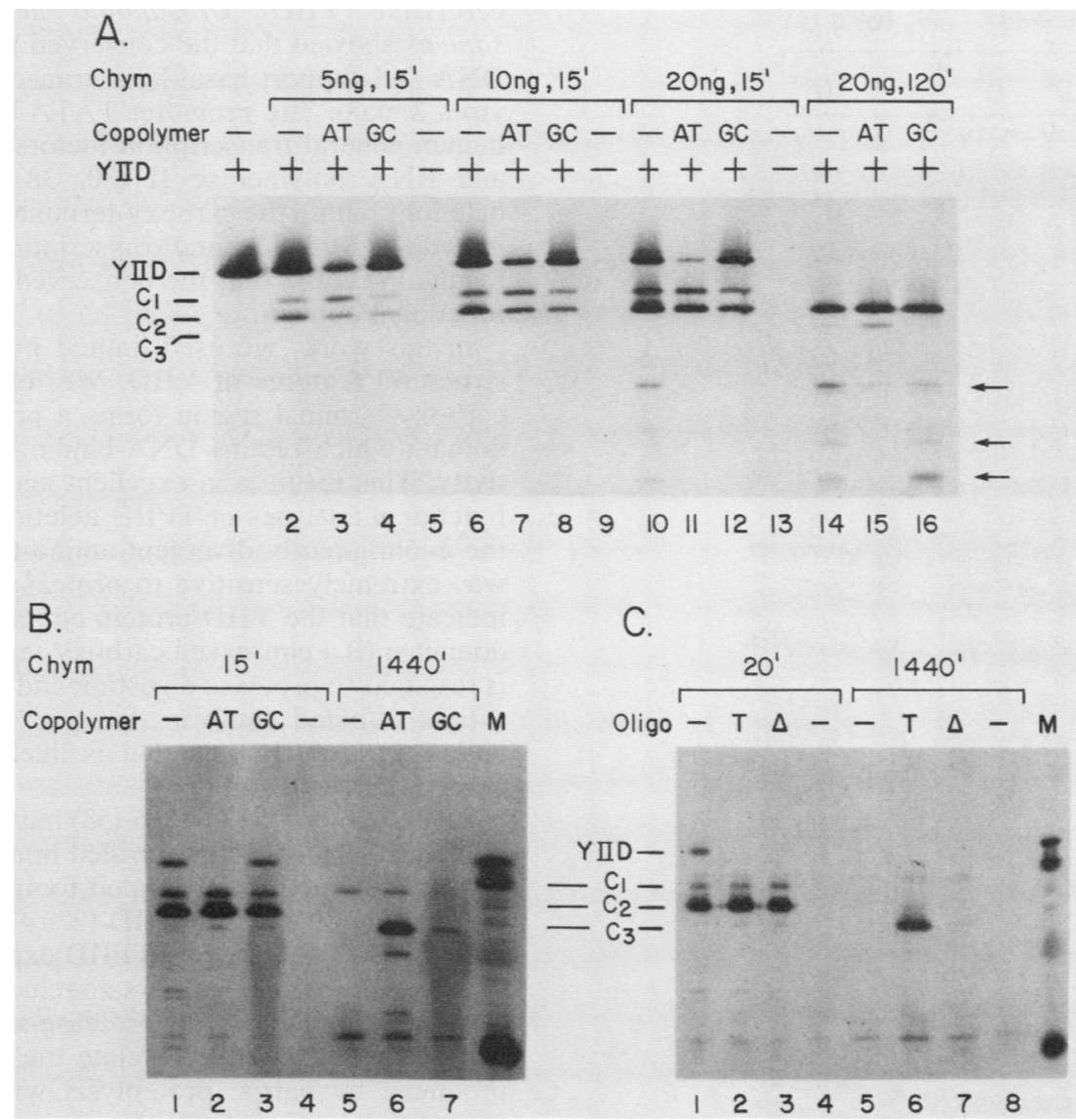

FIG. 7. Induction by consensus TATA sequences of protease patterns distinct from non-TATA-containing DNA. (A) Silver-stained polyacrylamide gels of early chymotrypsin digestion patterns. YIID (250 ng) was incubated with $500 \mathrm{ng}$ of poly(dA-dT) (AT; lanes 3, 7, 11, and 15), $500 \mathrm{ng}$ of poly (dG-dC) (GC; lanes $4,8,12$, and 16) or buffer alone (-; lanes $2,6,10$, and 14$)$ for 30 min at $30^{\circ} \mathrm{C}$. Chymotrypsin (Chym) was added to reaction mixtures at a concentration of $5 \mathrm{ng}$ (lanes 2 to 5), $10 \mathrm{ng}$ (lanes 6 to 9), or $20 \mathrm{ng}$ (lanes 10 to 16) for 15 min (lanes 2 to 13) or $120 \mathrm{~min}$ (lanes 14 to 16 ) at $30^{\circ} \mathrm{C}$. Arrows indicate cleavage absent from the poly (dA-dT)-induced cleavage at the latest time point (lanes 14 to 16). (B) Later time points demonstrate stabilization. YIID was incubated with poly(dA-dT) (AT; lanes 2 and 6), poly(dG-dC) (GC; lanes 3 and 7), or buffer alone (-; lanes 1 and 5) as described above. Then $20 \mathrm{ng}$ of chymotrypsin (Chym) was added to samples for 15 min (lanes 1 to 4) or for $1,440 \mathrm{~min}$ (lanes 5 to 7) at $30^{\circ} \mathrm{C}$. Lane $\mathrm{M}$ is a marker lane. (C) The E1B TATA-containing oligonucleotide stabilizes the YIID core. YIID ( $250 \mathrm{ng}$ ) was incubated with $200 \mathrm{ng}$ of the E1B TATA oligonucleotide; (T; lanes 2 and 6$), 200 \mathrm{ng}$ of a control oligonucleotide ( $\Delta$; lanes 3 and 7), or buffer alone (-; lanes 1 and 5) for $30 \mathrm{~min}$ at $30^{\circ} \mathrm{C}$. Then $20 \mathrm{ng}$ of chymotrypsin (Chym) was added for $20 \mathrm{~min}$ (lanes 1 to 4) or 1,440 min (lanes 5 to 8 ) at $30^{\circ} \mathrm{C}$. Major chymotrypsin cleavage products are indicated as $C_{1}, C_{2}$, and $C_{3}$.

7B; compare lanes 6 and 7). Moreover, we found that the E1B TATA box-containing oligonucleotide could stabilize the protease-resistant core to extensive digestion by chymotrypsin, while the control oligonucleotide $\Delta$, lacking a consensus TATA box, failed to stabilize the YIID core against extensive chymotrypsin digestion (Fig. 7C, lanes 6 and 7). These results are consistent with the hypothesis that binding of YIID to TATA box DNA involves a conformational change in the protein that can be detected by both facilitated protease cleavage in the amino terminus at early time points and stabilization of a resistant core at longer time points.

Proteolysis of the amino terminus eliminates temperaturedependent DNA binding. We previously observed that YIID bound to TATA sequences at $30^{\circ} \mathrm{C}$ but not a $0^{\circ} \mathrm{C}(50)$. To better understand the structural basis for this temperature dependence of DNA binding by YIID, we examined the ability of trypsin-treated YIID to bind to the E1B TATA element at $0^{\circ} \mathrm{C}$ (Fig. 8). We found that in contrast to wild-type YIID, the trypsin-digested YIID bound efficiently at $0^{\circ} \mathrm{C}$ (Fig. 8; compare lanes 8 and 9). Although the trypsin-digested YIID bounds with a two- to fourfold higher affinity than did the wild-type protein at $30^{\circ} \mathrm{C}$, comparison of binding affinities at $0^{\circ} \mathrm{C}$ indicated a much greater difference. At no concentrations tested could we observe DNA-binding activity for the wild-type YIID when incubated at $0^{\circ} \mathrm{C}$, while we observed full protection of the TATA sequence with 16 ng of the trypsin-treated YIID under identical experimental conditions. We conclude from this result that the aminoterminal domain is responsible for the temperature-dependent DNA binding of YIID to TATA sequences. One interpretation which is consistent with the proteolysis data is that thermal energy is required for a conformational change in the amino terminus necessary for DNA binding.

Evolutionary evidence for two domains of the TFIID molecule. Figure 9 summarizes data from Southern blotting experiments with various species of fungi related to $S$. cerevisiae, using probes from three different regions of the YIID gene. Among budding yeasts, we found high conservation of the sequences $3^{\prime}$ of the $B g$ III site, which maps to residue 60 . In contrast to this highly conserved carboxy- 


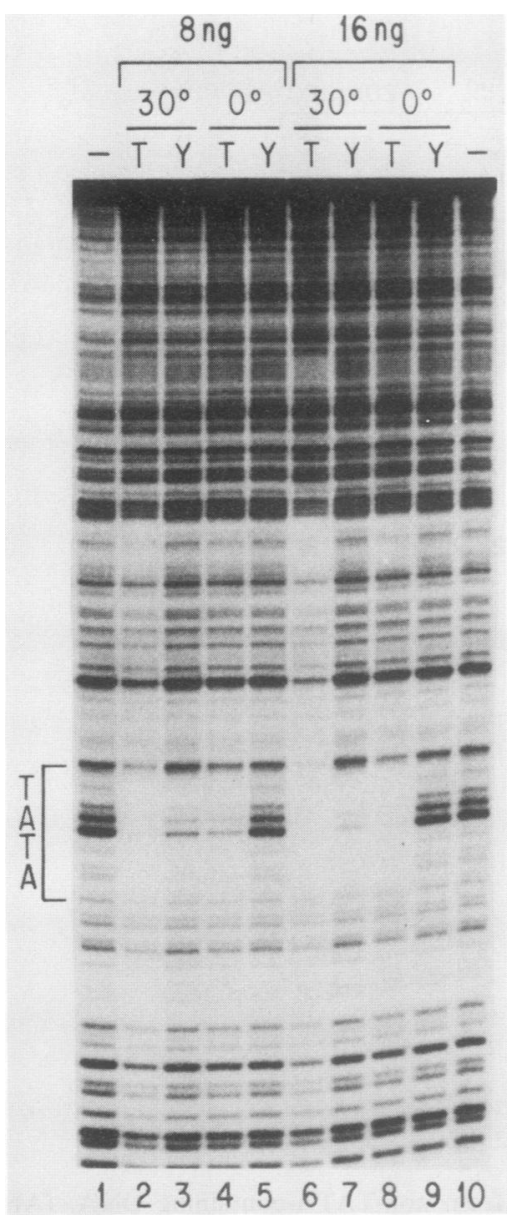

FIG. 8. Elimination of temperature dependence of DNA binding by proteolytic cleavage of the YIID amino terminus. DNase I footprinting of full-length YIID (Y) or trypsin-treated YIID (T) on the E1B promoter was performed at 0 or $30^{\circ} \mathrm{C}$ for $45 \mathrm{~min}$ with either 8 or $16 \mathrm{ng}$ of protein, as indicated above the lanes. The material used for lanes $Y$ and $T$ was the same as that shown in Fig. 1 (lanes 2 and 8). After $45 \mathrm{~min}$ of binding at 0 or $30^{\circ} \mathrm{C}$, samples were treated with DNase I for $30 \mathrm{~s}$ at $22^{\circ} \mathrm{C}$. The protected TATA sequences are indicated by a bracket at the left.

terminal sequence, the $5^{\prime} 200$-bp region, encoding the aminoterminal 60 residues, were highly diverged, even between different species of the genus Saccharomyces. This rapid evolutionary divergence correlates with the protease sensitivity of this region. Sequencing analysis has shown that the major cleavage sites for chymotrypsin and trypsin fall within 8 to 17 amino acid residues of the boundary between the species-specific amino terminus and the highly conserved carboxy-terminal domain $(7,12,17,19,23-25,28,31,38$, 49).

\section{DISCUSSION}

YIID contains at least two protein domains. The sequences of TFIID proteins from several highly diverged species $(7$, $12,17,19,23-25,28,31,38,49)$ have shown that in each case the proteins contain a homologous carboxy-terminal sequence of approximately 180 residues and distinct speciesspecific amino-terminal sequences varying in length. Functional analyses of deletion mutants of TFIID from $S$. cerevisiae (YIID), Drosophilia melanogaster, and Homo sapiens showed that the conserved region alone can bind to DNA and support basal-level transcription from the adenovirus 2 major late promoter TATA box in conjunction with human general transcription factors TFIIA, -B, -E, and -F and RNA polymerase II $(30,38,42)$. Moreover, small deletions within the carboxy-terminal conserved region eliminated DNA binding and transcriptional activity (30). These results indicated that the conserved region forms a distinct functional domain.

In this work, we used limited proteolysis to investigate structural features of YIID. We found that the conserved carboxy-terminal region forms a protease-resistant protein domain which retains DNA-binding and transcriptional activity. This result is in excellent agreement with the earlier functional analyses of TFIID deletion mutants. In contrast, the evolutionarily divergent amino-terminal region of YIID was extremely sensitive to protease digestion. The results indicate that the YIID protein contains at least two protein domains: (i) a conserved carboxy-terminal core domain that is resistant to protease digestion and therefore likely to be in a tightly folded conformation and (ii) a protease-sensitive amino-terminal domain that is likely to be in a more extended conformation.

Van Dyke and Sawadogo (58) have also reported a proteolysis study of partially purified human TFIID. Mild proteolysis eliminated the extended footprint observed with this preparation of human TFIID $(27,47,57)$ but not observed with YIID (5) and human TFIID expressed from the cloned cDNA $(31,38)$. The authors concluded that TFIID consists of a core domain and a protease-sensitive tail. However, they were not able to correlate the change in the footprint produced by partial proteolysis with cleavage of specific polypeptides. Consequently, it is not clear whether the altered footprint was due to cleavage of the $38-\mathrm{kDa}$ human TFIID polypeptide or other polypeptides present in the partially purified protein fraction. YIID does not produce the extended footprint observed with partially purified human TFIID, and partial proteolysis to produce the carboxyterminal core did not alter the DNase I footprint (Fig. 3).

Evidence that DNA binding requires a conformational change in YIID. Several different results reported here are best explained by the model that DNA binding requires a conformational change in the YIID amino-terminal domain. Full-length YIID does not bind to TATA boxes at $0^{\circ} \mathrm{C}$ under transcription reaction conditions $(50)$. In contrast, the trypsin-resistant carboxy-terminal core does bind to the E1B TATA box under the same conditions (Fig. 8). This result is consistent with the hypothesis that the amino-terminal domain undergoes a conformational change required for DNA binding. In this interpretation, at $0^{\circ} \mathrm{C}$ the amino terminus sterically blocks access of the YIID binding site to the TATA box. Thermal energy would be required for a conformational change in the molecule which moves the amino-terminal domain out of the way. This conformational change would not be required when the amino terminus is removed by proteolysis, explaining why the carboxy-terminal core can bind at $0^{\circ} \mathrm{C}$.

Elimination of the amino terminus resulted in a two- to fourfold increase in the affinity of YIID for the E1B TATA box, as assayed by DNase I footprinting (Fig. 3). This result can also be explained if DNA binding requires an energydependent conformational change in the amino terminus of YIID. Removal of the flexible amino terminus would then reduce the energy requirements for binding and increase the affinity of YIID for DNA, as observed. 
If the amino terminus undergoes a conformational change upon DNA binding, one might expect to detect differences in proteolysis in this region of the protein between free YIID and DNA-bound YIID. Facilitated proteolysis by ligand binding has been used as an argument for conformational change in the $E$. colic cyclic AMP receptor protein, CRP. In the presence of cyclic AMP, CRP becomes susceptible to cleavage by several proteases, which results in the loss of the DNA-binding domain and the generation of the $\alpha$-core of CRP $(11,44)$. Altered protease patterns induced by DNA binding also have been observed for transcription factors PRTF (56) and C/EBP (51) and have been interpreted as being due to conformational changes induced by DNA binding.

DNA binding did, in fact, alter the pattern of proteolysis of YIID for each of the three proteases tested. A strong $S$. aureus V8-hypersensitive cleavage site was induced in the amino terminus by DNA binding (Fig. 6). Similarly, trypsin (Fig. 6B) and chymotrypsin (Fig. 7A and B) both digested the amino terminus more rapidly when the protein was bound to DNA. One can imagine that binding of YIID to DNA might increase its susceptibility to a protease which fortuitously contains positive charges at a particular surface of the enzyme such that the active site of the protease becomes more readily oriented toward the YIID amino terminus when YIID is bound to the highly negatively charged DNA. However, it seems very unlikely that the same explanation can account for the increased sensitivity of the amino terminus to digestion by all three proteases tested. Rather, it seems much more likely that DNA binding causes the conformation of the amino terminus near the junction with the conserved carboxy-terminal core to become more extended so that susceptible cleavage sites more readily fit into the active sites of these three different proteases with distinct specificities.

Alone, each of these results, the ability of the YIID core to bind to the E1B TATA box at $0^{\circ} \mathrm{C}$ in contrast to full-length YIID, the increased affinity of the YIID core for the E1B TATA box compared with that of full-length YIID at $30^{\circ} \mathrm{C}$, and the hypersensitivity of the amino-terminal domain to protease digestion for DNA-bound YIID compared with free YIID, might not be taken as strong evidence for a conformational change. Together, however, these three quite different types of experimental results are best explained by the model that a conformational change in the amino terminus is required for DNA binding. What might the significance of such a conformational change be? The proposed conformational change might increase the affinity of TFIID for other general transcription factors such as TFIIA and TFIIB, which add to the DNA-protein complex in subsequent steps in the assembly of the complete preinitiation complex $(4,57)$. This might help to ensure that the assembly of the complex and subsequent interaction with RNA polymerase II occurs only on TFIID bound to DNA.

DNA binding stabilizes the YIID core. In contrast to the YIID amino terminus, DNA binding stabilized the carboxyterminal core domain against conditions of protease digestion that completely degraded free YIID (Fig. 5 to 7). This result suggests that DNA binding increases the rigidity of the core domain. This would prevent susceptible cleavage sites from fitting into active sites of the proteases. We cannot rule out the possibility that DNA binding results in steric blocking of crucial protease sites in YIID. However, the ability of a 29-bp oligonucleotide to protect YIID from complete digestion by three proteases with different specificities does not seem as likely as the interpretation that the overall tertiary structure of the carboxy-terminal core domain is stabilized. These results argue further that the entire 180 conserved carboxy-terminal residues of TFIID form a single, unusually large DNA-binding domain. Ligand-induced protease resistance has been used as evidencé for conformational changes in the yeast copper-binding transcription factor Ace 1 (16). The Ace 1 protein becomes weakly resistant to trypsin in the presence of bound copper ion and strongly resistant when bound to DNA. This DNA-induced resistance to proteolytic attack observed for Ace 1 may be analogous to the TATA-induced protection observed for YIID.

Increased DNA-binding activity of the YIID core as assayed by the electrophoresis mobility shift assay. YIID does not remain stably bound to DNA during electrophoresis in neutral polyacrylamide gels unless (i) the gels contain $\mathbf{M g}^{2+}$ and glycerol (29) or (ii) the general transcription factor TFIIA is included in the binding reaction and associates with the DNA protein complex (4). In contrast, we found that the proteolyzed YIID core did form a stable complex with TATA box DNA in a standard gel electrophoresis mobility shift assay (Fig. 2). This result indicates that the YIID amino terminus interferes with this assay either by interacting with the polyacrylamide matrix or by somehow causing release of the DNA during electrophoresis. This is not a property of the human TFIID amino terminus, since intact human TFIID is active in this assay under standard conditions $(25,31,38)$. Horikoshi et al. (30) reported that deletion of the YIID amino terminus increased the apparent DNA-binding activity in the electrophoretic assay, even in gels containing $\mathbf{M g}^{2+}$ and glycerol. The ability of TFIIA to stabilize the YIID-TATA box complex during electrophoresis is not the result of a significant increase in the affinity of YIID for TATA box DNA (18). Perhaps TFIIA sterically covers the region of the YIID amino-terminal domain that interferes with this particular assay or alters its conformation so that it no longer interferes.

The TFIID amino-terminal domain diverges significantly between budding yeasts. Cloning and sequencing of TFIID from $S$. cerevisiae $(7,12,19,28,49)$, Schizosaccharomyces pombe $(14,24)$, Arabidopsis thaliana $(17), D$. melanogaster (23), and $H$. sapiens $(25,31,38)$ has shown that the amino acid sequences $\mathbf{N}$ terminal to the core domain show little recognizable similarity. However, these organisms are distantly related in evolution. The data summarized in Fig. 9 shows that the amino-terminal domain also diverged rapidly between more closely related budding yeasts. To rapidly estimate the similarities between the amino- and carboxyterminal TFIID domains of different budding yeasts, we analyzed the homology between the regions of the YIID gene encoding these domains and DNA from several budding yeasts by Southern blotting. The results showed that the N-terminal region diverged rapidly even among four species of the same genus, Saccharomyces. Clearly, there is little selective pressure to maintain the sequence of the TFIID amino-terminal domain, even among closely related species. It has been suggested that the $\mathrm{N}$-terminal domain of TFIID mediates transcriptional activation by gene-specific transcription factors $(38,42)$. However, the Schizosaccharomyces pombe TFIID gene can replace the $S$. cerevisiae TFIID gene to yield viable cells, even though the two proteins have no recognizable sequence similarity in the amino-terminal domain (13). Nonetheless, we have found that deletion of residues 2 to 57 of the YIID gene in $S$. cerevisiae results in a significant decrease in the rate of cell growth (62). Apparently, whatever the function of the ami- 


Saccharomyces cerevisiae
Saccharomyces dairensis

FIG. 9. Conservation of regions in the YIID gene. The thick line depicts the open reading frame of the YIID gene; the arrow indicates the approximate transcription start site (49). Positions of restriction sites and the DNA fragments (in base pairs) used to probe digested yeast genomic DNA are indicated. A compilation of results from several Southern blots performed under identical conditions (see Materials and Methods) is presented: ++ , very strong hybridization signal; +, clearly visible hybridization signal; $-/+$, weak but detectable signal; -, no detectable signal; nd, not determined.

no-terminal domain is in vivo, it can be provided by widely divergent protein sequences.

\section{ACKNOWLEDGMENTS}

We thank Audrey Fowler for determination of amino-terminal peptide sequence, Carol Eng for technical assistance, and Qiang Zhou for expert advice and assistance.

This work was supported by postdoctoral fellowships PF3380 from the American Cancer Society to P.M.L., PF2715 from the American Cancer Society to M.C.S., and J-3-89 from the California Division of the American Cancer Society to C.C.K. and by National Cancer Institute grant CA25235 to A.J.B.

\section{REFERENCES}

1. Boulanger, P. A., N. D. L'Etoile, A. J. Berk. 1989. A DNAbinding domain of human transcription factor IIIC2. Nucleic Acids Res. 17:7761-7770.

2. Bradford, M. M. 1976. A rapid and sensitive method for the quantitation of microgram quantities of protein utilizing the principle of protein-dye binding. Anal. Biochem. 72:248-254.

3. Breathnach, R., and P. A. Chambon. 1981. Organization and expression of eukaryotic split genes. Annu. Rev. Biochem. 50:349-393.

4. Buratowski, S., S. Hahn, L. Guarente, and P. A. Sharp. 1989. Five intermediate complexes in transcription initiation by RNA polymerase II. Cell 56:549-561.

5. Buratowski, S., S. Hahn, P. A. Sharp, and L. Guarente. 1989 Function of a yeast TATA element-binding protein in a mammalian transcription system. Nature (London) 337:37-42.

6. Carcamo, J., S. Lobos, A. Merino, L. Buckbinder, R. Weinman,
V. Natarajan, and D. Reinberg. 1989. Factors involved in specific transcription by mammalian RNA polymerase II. J. Biol. Chem. 264:7704-7714.

7. Cavallini, B., I. Faus, H. Matthes, J. M. Chipoulet, B. Winsor, J. M. Egly, and P. Chambon. 1989. Cloning of the gene encoding the yeast protein BTF1Y, which can substitute for the human TATA box-binding factor. Proc. Natl. Acad. Sci. USA 86:98039807.

8. Cavallini, B., J. Huet, J.-L. Plassat, A. Sentenac, J.-M. Egly, and P. Chambon. 1988. A yeast activity can substitute for the HeLa cell TATA box factor. Nature (London) 334:77-80.

9. Davison, B. L., J. M. Egly, E. R. Mulvihill, and P. Chambon. 1983. Formation of stable preinitiation complexes between eukaryotic class B transcription factors and promoter sequences. Nature (London) 301:680-686.

10. Dignam, J. D., P. Martin, B. S. Shastry, and R. G. Roeder. 1983. Eukaryotic gene transcription with purified components. Methods Enzymol. 101:582-598.

11. Eileen, E., C. Pameno, and J. S. Krakow. 1978. Production and properties of the $\alpha$-core derivative from the cyclic adenosine monophosphate receptor protein of Escherichia coli. Biochemistry 17:2469-2473.

12. Eisenmann, D. M., C. Dollard, and F. Winston. 1989. Spt15, the gene encoding the yeast TATA binding factor TFIID, is required for normal transcription initiation in vivo. Cell 58:11831191.

13. Fikes, J. D., D. M. Becker, F. Winston, and L. Guarente. 1990. Striking conservation of TFIID in Schizosaccharomyces pombe and Saccharomyces cerevisiae. Nature (London) 346:291-294.

14. Fire, A., M. Samuels, and P. A. Sharp. 1984. Interactions between RNA polymerase II, factors, and template leading to accurate transcription. J. Biol. Chem. 259:2509-2516.

15. Flores, O., E. Maldonado, Z. Burton, J. Greenblatt, and D. 
Reinberg. 1988. Factors involved in specific transcription by mammalian RNA polymerase II. J. Biol. Chem. 263:1081210816.

16. Furst, P., S. Hu, R. Hackett, and D. Hamer. 1988. Copper activates metallothionein gene transcription by altering the conformation of a specific DNA binding protein. Cell 55:705717.

17. Gasch, A., A. Hoffmann, M. Horikoshi, R. G. Roeder, and N.-H. Chua. 1990. Arabidopsis thaliana contains two genes for TFIID. Nature (London) 346:390-394.

18. Hahn, S., S. Buratowski, P. A. Sharp, and L. Gurarente. 1989. Identification of a yeast protein homologous in function to the mammalian general transcription factor, TFIIA. EMBO J. 8:3379-3382.

19. Hahn, S., S. Buratowski, P. A. Sharp, and L. Guarente. 1989. Isolation of the gene encoding the yeast TATA binding protein TFIID: a gene identical to the SPT15 suppressor of Ty element insertions. Cell 58:1173-1181.

20. Hahn, S., S. Buratowski, P. A. Sharp, and L. Guarente. 1989. Yeast TATA-binding protein TFIID binds to TATA elements with both consensus and non-consensus DNA sequences. Proc. Natl. Acad. Sci. USA 86:5718-5722.

21. Hawley, D., and R. G. Roeder. 1985. Separation and partial characterization of three functional steps in transcription initiation by human RNA polymerase II. J. Biol. Chem. 260:81638172.

22. Hawley, D., and R. G. Roeder.1987. Functional steps in transcription initiation and reinitiation from the major late promoter in a HeLa nuclear extract. J. Biol. Chem. 262:3452-3461.

23. Hoey, T., B. D. Dynlacht, M. D. Peterson, B. F. Pugh, and R. Tjian. 1990. Isolation and characterization of the drosophila gene encoding the TATA box binding protein, TFIID. Cell 61:1179-1186

24. Hofimann, A., M. Horikoshi, C. K. Wang, S. Schroeder, P. A. Weil, and R. G. Roeder. 1990. Cloning of the Schizosaccharomyces pombe TFIID gene reveals a strong conservation of functional domains present in Saccharomyces cerevisiae TFIID. Genes Dev. 4:1141-1148.

25. Hofimann, A., E. Sinn, T. Yamamoto, J. Wang, A. Roy, M. Horikoshi, and R. G. Roeder. 1990. Highly conserved core domain and unique $\mathbf{N}$ terminus with presumptive regulatory motifs in a human TATA factor (TFIID). Nature (London) 346:387-390.

26. Horikoshi, M., M. F. Carey, H. Kakidani, and R. G. Roeder. 1988. Mechanism of action of a yeast activator: direct effect of Gal4 derivatives on mammalian TFIID-promoter interactions. Cell 54:665-669.

27. Horikoshi, M., T. Hai, Y.-S. Lin, M. R. Green, and R. G. Roeder. 1988. Transcription factor ATF interacts with the TATA factor to facilitate establishment of a preinitiation complex. Cell 54:1033-1042.

28. Horikoshi, M., C. K. Wang, H. Fuji, J. A. Cromlish, P. A. Weil, and R. G. Roeder. 1989. Cloning and structure of a yeast gene encoding a general transcription initiation factor TFIID that binds to the TATA box. Nature (London) 341:299-303.

29. Horikoshi, M., C. K. Wang, H. Fuji, J. A. Cromlish, P. A. Weil, and R. G. Roeder. 1989. Purification of a yeast TATA boxbinding protein that exhibits human transcription factor IID activity. Proc. Natl. Acad. Sci. USA 86:4843-4847.

30. Horikoshi, M., T. Yamamoto, Y. Ohkuma, P. A. Weil, and R. G. Roeder. 1990. Analysis of structure-function relationships of yeast TATA box binding factor TFIID. Cell 61:1171-1178.

31. Kao, C. C., P. M. Lieberman, M. C. Schmidt, Q. Zhou, R. Pei, and A. J. Berk. 1990. The human TATA-box binding factor TFIID, expressed in vitro is transcriptionally active. Science 248:1646-1649.

32. Leong, K., L. Brunet, and A. J. Berk. 1988. Factors responsible for the higher transcriptional activity of extracts of adenovirusinfected cells fractionate with the TATA box transcription factor. Mol. Cell. Biol. 8:1765-1774.

33. Lieberman, P. M., J. M. Hardwick, J. Sample, G. S. Hayward, and S. D. Hayward. 1990. The Zta trans-activator involved in induction of lytic cycle gene expression in Epstein-Barr virus infected lymphocytes binds to both AP-1 and ZRE sites in target promoter and enhancer regions. J. Virol. 64:1143-1155.

34. Maniatis, T., S. Goodbourn, and J. A. Fischer. 1987. Regulation of inducible and tissue-specific gene expression. Science 236: 1237-1245.

35. Marzouki, N., S. Camier, A. Ruet, A. Moenne, and A. Sentenac. 1986. Selective proteolysis defines two DNA binding domains in yeast transcription factor $\tau$. Nature (London) 323:176-178.

36. Matsui, T., J. Segall, P. A. Weil, and R. G. Roeder. 1980. Multiple factors required for accurate initiation of transcription by purified RNA polymerase II. J. Biol. Chem. 255:1199211996.

37. Mitchell, P. J., and R. Tjian. 1989. Transcription regulation in mammalian cells by sequence-specific DNA binding proteins. Science 245:371-378.

38. Peterson, M. G., N. Tanese, B. F. Pugh, and R. Tjian. 1990. Functional domains and upstream activation properties of cloned human TATA binding protein. Science 248:1625-1630.

39. Ptashne, M. 1986. A genetic switch. Cell Press, Cambridge, Mass.

40. Ptashne, M. 1988. How eukaryotic transcription activators work. Nature (London) 335:683-689.

41. Ptashne, M., and A. A. F. Gann. 1990. Activators and targets. Nature (London) 346:329-331.

42. Pugh, B. F., and R. Tjian. 1990. Mechanism of transcriptional activation by Sp1: evidence for coactivators. Cell 61:1187-1197.

43. Reinberg, D., and R. G. Roeder. 1987. Factors involved in specific transcription by mammalian RNA polymerase II. J. Biol. Chem. 262:3310-3321.

44. Ren, Y. L., S. Garges, S. Adhya, and J. S. Krakow. 1988 Cooperative DNA binding of heterologous proteins: evidence for contact between the cyclic AMP receptor protein and RNA polymerase. Proc. Natl. Acad. Sci. USA 85:4138-4142.

45. Saltzman, A. G., and R. Weinman. 1989. Promoter specificity and modulation of RNA polymerase II transcription. FASEB J. 3:1723-1733.

46. Sauer, R. T., D. L. Smith, and A. D. Johnson. 1988. Flexibility of the yeast $\alpha 2$ repressor enables it to occupy the ends of the operator, leaving the center free. Genes Dev. 2:807-816.

47. Sawadogo, M., and R. G. Roeder. 1985. Interaction of a genespecific transcription factor with the adenovirus major late promoter upstream of the TATA box region. Cell 43:165-175.

48. Sawadogo, M., and R. G. Roeder. 1985. Factors involved in specific transcription by human RNA polymerase II: analysis by a rapid and quantitative in vitro assay. Proc. Natl. Acad. Sci. USA 82:4394-4398.

49. Schmidt, M. C., C. C. Kao, R. Pei, and A. J. Berk. 1989. Yeast TATA-box transcription factor gene. Proc. Natl. Acad. Sci. USA 86:7785-7789.

50. Schmidt, M. C., Q. Zhou, and A. J. Berk. 1989. Sp1 activates transcription without enhancing DNA-binding activity of the TATA box factor. Mol. Cell. Biol. 9:3299-3307.

51. Shuman, J. D., C. R. Vinson, and S. L. McKnight. 1990. Evidence of changes in protease sensitivity and subunit exchange rate on DNA binding by C/EBP. Science 249:771773.

52. Smale, S. T., M. C. Schmidt, A. J. Berk, and D. Baltimore. 1990. Transcriptional activation by $\mathrm{Spl}$ as directed through TATA or initiator: specific requirement for mammalian transcription factor IID. Proc. Natl. Acad. Sci. USA 87:4509-4513.

53. Smith, D. R., I. J. Jackson, and D. D. Brown. 1984. Domains of the positive transcription factor specific for the Xenopus $5 \mathrm{~S}$ RNA gene. Cell 37:645-652.

54. Southern, E. 1975. Detection of specific sequences among DNA fragments separated by gel electrophoresis. J. Mol. Biol. 98: 503-517.

55. Stringer, K. F., C. J. Ingles, and J. Greenblatt. 1990. Direct and selective binding of an acidic transcriptional activation domain to the TATA-box factor TFIID. Nature (London) 345:783-786.

56. Tan, S., and T. J. Richmond. 1990. DNA binding-induced conformational change of the yeast transcriptional activator PRTF. Cell 62:367-377.

57. Van Dyke, M. W., R. G. Roeder, and M. Sawadogo. 1988. 
Physical analysis of transcription pre-initiation complex assembly on a class II gene promoter. Science 241:1335-1338.

58. Van Dyke, M. W., and M. Sawadogo. 1990. DNA-binding and transcriptional properties of human transcription factor TFIID after mild proteolysis. Mol. Cell. Biol. 10:3415-3420.

59. Workman, J. L., and R. G. Roeder. 1987. Binding of transcription factor TFIID to the major late promoter during in vitro nucleosomal assembly potentiates subsequent initiation by
RNA polymerase II. Cell 51:613-622.

60. Wray, W., T. Boulikas, V. P. Wray, and R. Hancock. 1981. Silver staining of proteins in polyacrylamide gels. Anal. Biochem. 118:197-203.

61. Wu, L., D. Rosser, M. C. Schmidt, and A. J. Berk. 1987. A TATA box implicated in E1A transcriptional activation of a simple adenovirus 2 promoter. Nature (London) 326:512-515.

62. Zhou, Q., M. C. Schmidt, and A. J. Berk. Unpublished data. 